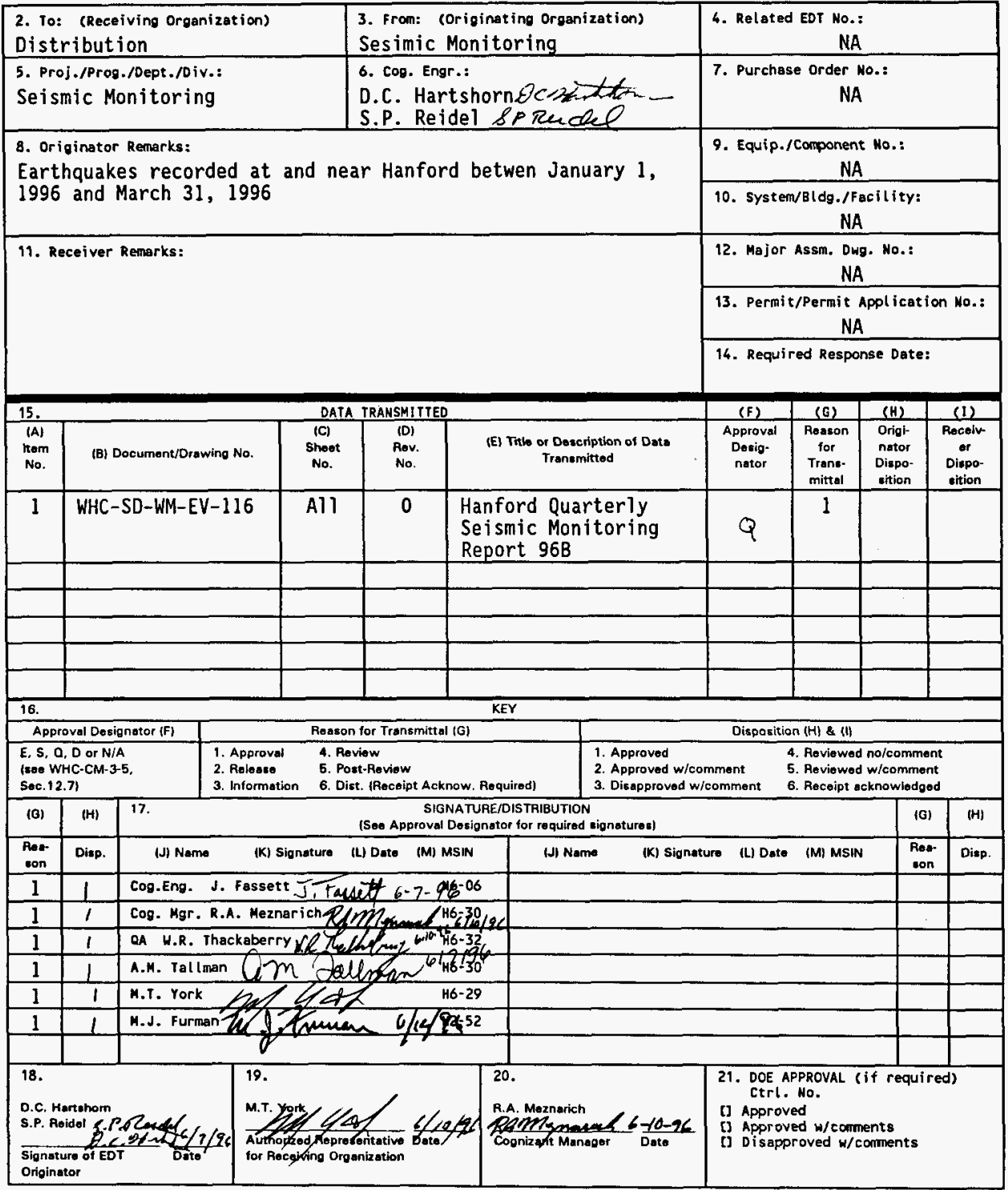




\title{
Quarterly Seismic Monitoring Report 96B
}

\author{
D.C. Hartshorn
}

S.P. Reidel

Westinghouse Hanford Co., Richland, WA 99352

U.S. Department of Energy Contract DE-ACO5-87RL10930

EDT/ECN: 610760 UC: 903

Org Code: 8H200 Charge Code: R4VA3

B\&R Code: EW3120100 Total Pages: 29

Key Words: Seismicity, Seismic Monitoring, Earthquakes, Tectonics

Abstract: This report summarizes the location, magnitude, and other pertinent information on earthquakes recorded on and near the Hanford Site by Westinghouse Seismic Monitoring during the period encompassing January 1, 1996 to March 31, 1996.

TRADEMARK DISCLAIMER. Reference herein to any specific commercial product, process, or service by trade name, trademark, marufacturer, or otherwise, does not necessarily constitute or imply its endorsement, recommendation, or favoring by the United States Government or any agency thereof or its contractors or subcontractors.

Printed in the United States of America. To obtain copies of this document, contact: WHC/BCS Document Control Services, P.O. Box 1970, Mailstop H6-08, Richland WA 99352, Phone (509) 372-2420; Fax (509) 376-4989.
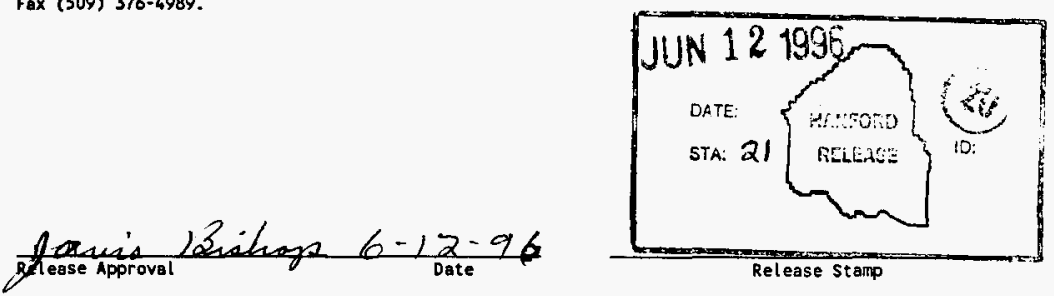

\section{Approved for Public Release}




\section{Hanford Quarterly}

Seismic Report 96B

Seismicity On and Near the

Hanford Site, Pasco Basin,

Washington, January 1, 1996

to March 31, 1996

Prepared for the U.S. Department of Energy

Office of Environmental Restoration and

Waste Management

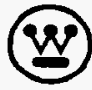

Westinghouse

Hanford Company Richland, Washington

Management and Operations Contractor for the

U.S. Department of Energy under Contract DE-ACO6-87RL 10930 
LECAL DISCLAMER

This repont was prepared as an account of work sponsored by an agency of the United States Government. Neither the United States Government nor any agency thereof, nor any of their omployees, nor any of their contractors, subcontractors or their employees, makes any warrenty, express or implied, or assumes any legal liability or responsibility for the accuracy, completeness, or any third party's use or the results of such use of any information, epparatus, product, or procass disclosed, or represents that its use would not infringe privately owned rights. Reference herein to any specific commercial product, process, or service by trade name, trademark, manufacturer, or otherwise, does not necessarily constitute or imply its endorsement, recommendation, or favoring by the United States Government of any agency thereof or its contractors or subcontractors. The views and opinions of euthore expressed herein do not necessarily state or reflect those of the United States Government or any agency thereof.

This report hes been reproduced from the best available copy. Available in paper copy and microfiche.

Available to the U.S. Department of Energy and its contrsctors from

Office of Sciantific and Technical Infomation

P.O. Box 62

Oak Ridge, TN 37831

(615) 576-8401

Available to the public from the U.S. Departmant of Commerce Netional Technicel Information Service

$\mathbf{5 2 8 5}$ Port Royel Rood

Springfield, VA 22161

(703) 487-4650

Printed in the United States of Americe

DISCLM- .CHP $\{1-91\}$ 
WHC-SD-WM-EV-116, Rev. 0

CONTENTS

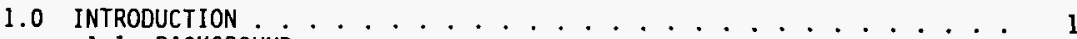

1.1 BACKGROUND . . . . . . . . . . . . . . . . . . 1

1.2 PURPOSE $\ldots \ldots \ldots \ldots$

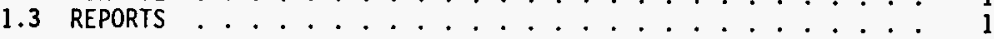

2.0 NETWORK OPERATIONS .................. 2

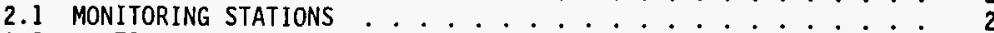

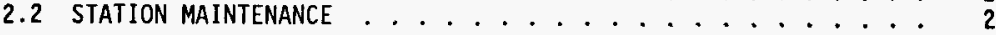

3.0 EXPLANATION OF MAGNITUDE AND VELOCITY MODEL .......... 8

3.1 CODA AMPLITUDE MAGNITUDE $\ldots \ldots \ldots \ldots$

3.2 VELOCITY MODEL . . . . . . . . . .

4.0 GEOLOGY AND TECTONIC ANALYSIS .............. 13

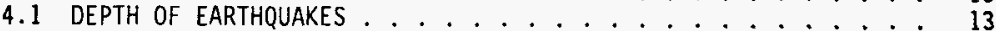

4.2 TECTONIC PATTERN $\ldots \ldots \ldots \ldots$

4.3 CURRENT TECTONIC ACTIVITY $\ldots \ldots$

4.3.1 Reverse/Thrust Faults on Major Anticlinal Ridges . . 18

4.3.2 Secondary Structures on Main Anticlinal Ridges.... 18

4.3.3 Swarm Area Activity ............ 18

4.3.4 Random or Floating Event Areas . . . . . . . . . 19

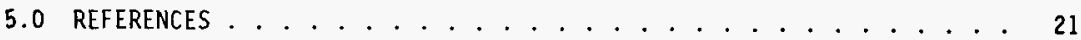




\section{LIST OF FIGURES}

1 Locations of Sejsmograph Stations . . . . . . . . . . . . . . 4

2 Locations of Seismograph Stations in the Eastern Washington

Regional Network . . . . . . . . . . . . . . . . . 6

3 Located Earthquakes Magnitude $1.0^{\circ}$ and Greater: January 1, 1996, and March 31, 1996 .................... . . 15

4 Locations of All FY 1996 Events: October 1, 1995, and March 31, 1996 .................... . . 16

5 Structural and Tectonic Map of Columbia Bas in Showing Major Seismic Source Structures . . . . . . . . . . . . . . . 17

\section{LIST OF TABLES}

1 Stations Used for Location of Events . . . . . . . . . . . . . . 3

2 Station Locations for the Eastern Washington Regional Network . . . . 5

3 Seismic Channel Operational Time.................. . 7

4 Velocity Model for the Columbia Basin . . . . . . . . . . . . . . . 9

5 Seismic Event Data. . . . . . . . . . . . . . . . . . . . 10 


\section{TERMS}

BWIP

CAM

CRBG

CUT

DOE

EWRN

FY

GBB

GPS

HSN

HTS

NEL

RAW

RC1

SMART

USGS

WHC
Basalt Waste Isolation Project

Coda Amplitude Magnitude

Columbia River Basalt Group

Coordinated Universal Time

U.S. Department of Energy

Eastern Washington Regional Network

fiscal year

Gable Butte

Global Positions Satellite System

Hanford Seismic Network

Hanford Technical Services

Neison Butte

Rattlesnake Mountain-Wallula Alignment

Royal City

Seismic Monitoring Analysis and Repair Team United States Geological Survey

Westinghouse Hanford Company 
WHC-SD-WM-EV-116, Rev. 0

This page intentionally left blank. 
WHC-SD-WM-EV-116, Rev. 0

\subsection{INTRODUCTION}

\subsection{BACKGROUND}

Seismic monitoring at the Hanford Site was established in 1969 by the United States Geological Survey (USGS) under a contract with the Atomic Energy Commission. In 1975 the University of Washington assumed responsibility for and expanded the network. In 1979 the Basalt Waste Isolation Program (BWIP) became responsible for collecting seismic data for the site as part of site characterization. Rockwell International Operations followed by Westinghouse Hanford Company (WHC), Geosciences Group, operated the local network and were the contract technical advisors for the Eastern Washington Regional Network operated by the University of Washington. Funding ended for BWIP in December 1988. Seismic monitoring and the University of Washington contract was then transferred WHC's Environmental Division.

Seismic monitoring is currently assigned to WHC's Hanford Technical Services (HTS), part of the Environmental Division. The Seismic Monitoring Analys is and Repair Team (SMART) operates, maintains, and analyzes data from the Hanford Seismic Network (HSN), extending the site historical seismic database and fulfilling U.S. Department of Energy, Richland Operations Office requirements and orders. The Seismic Monitoring Analysis and Repair Team also maintains the Eastern Washington Regional Network (EWRN). The University of Washington uses the data from the EWRN and other seismic networks in the Northwest to provide the SMART with necessary regional input for the seismic hazards analysis at the Hanford Site.

\subsection{PURPOSE}

The SMART is tasked to provide an uninterrupted collection of high-quality seismic data from a network on and near the Hanford Site, locate and identify sources of seismic activity, monitor changes in the historical pattern of seismic activity at the Hanford Site, and build a seismic database. This database contains only "Local" earthquakes. "Local" earthquakes are defined for this report and database as earthquakes that occur within 46 degrees to 47 degrees West Longitude and 119 degrees to 120 degrees North Latitude. The data are used by the SMART, Waste Management, and engineering activities at the Hanford Site to evaluate seismic hazards and seismic design for the Site.

\subsection{REPORTS}

The SMART issues brief monthly activity reports, quarterly reports with discussion of local activity, an annual catalog of earthquake activity on and near the Site, and bulletins on special-interest local seismic events. The SMART also provides information and reports to other functions, as weil as educational assistance to area schools and programs when the assistance is requested and approved, and the workload permits. 


\subsection{NETWORK OPERATIONS}

\subsection{MONITORING STATIONS}

The Hanford Seismic Network and the Eastern Washington Regional Network have 40 individual stations. Sixteen sites are shared by both networks, so that the Hanford Seismic Network has 21 sites (Table 1 and Figure 1) and the Eastern Washington Regional Network has 35 (Table 2 and Figure 2). The networks have 44 combined data channels because Gable Butte and Royal City are three-component sites, each consisting of one vertical, one north-south horizontal and one east-west horizontal data channel. Both networks use 15 additional telemetry relay sites. All station data links pass through at least one of these relay sites. Some data links cross as many as three relay sites. The last section of the data link for all channels is commercial telephone lines. Three to eight channels are multiplexed per telephone line.

Most stations and three relay sites are powered by solar panels and batteries. A major outage is considered to be a failure of the HSN data recording computer or three or more data channels. The extended failure of a relay site or a telephone line quickly becomes a major outage.

\subsection{STATION MAINTENANCE}

The HSN's station outages and a review of the station maintenance for the current quarter can be found in the Seismic Monitoring monthiy reports. Table 3 shows the percentage of time the channe? was operational for the period. A site in the EWRN, Nelson Butte (NEL), is not working. Access to repair NEL is prevented by snow, damaged roads, and the site's remote location. The site is located in the northern Cascades at 1,490 meters elevation. 
Table 1. Stations Used for Location of Events.

\begin{tabular}{|c|c|c|c|c|}
\hline \multicolumn{5}{|c|}{$\begin{array}{l}\text { This table lists stations of the Hanford Seismic Network. The first colum is the three-letter seismic } \\
\text { station designator. This is followed by the latitude-north in degrees, minutes, and hundredth of } \\
\text { minutes; the longitude-west in degrees, minutes, and hundredth of minutes; elevation above sea level in } \\
\text { meters; and the full station name. An asterisk before the three-letter designator means it is a three- } \\
\text { component station. The locations of the stations were derived from a Global Positions Satellite system } \\
\text { (GPS). }\end{array}$} \\
\hline Station & $\begin{array}{l}\text { Latitude } \\
\text { Deg.Min.N }\end{array}$ & $\begin{array}{l}\text { Long i tude } \\
\text { Deg.Min.W }\end{array}$ & $\begin{array}{c}\text { Elevation in } \\
\text { Meters }\end{array}$ & Station Nane \\
\hline BEN & $46-31.13$ & 119.43 .02 & 340 & Benson Ranch \\
\hline BRV & $46 \cdot 49.12$ & $119-59.47$ & 920 & Black Rock Valley \\
\hline BVu & $46-48.66$ & 119.52 .99 & 670 & Beverly, Washingt on \\
\hline CRF & $46-49.50$ & $119-23.22$ & 189 & Corfu, Washington \\
\hline EI3 & $46-34.64$ & $118-56.25$ & 286 & Eltopis Three \\
\hline$* 68 B$ & $46-36.49$ & $119-37.62$ & 177 & Gable Butte \\
\hline GBL & $46-35.92$ & $119-27.58$ & 330 & Gable Mountain \\
\hline $\mathrm{H} 2 \mathrm{O}$ & $46-23.75$ & $119-25.38$ & 158 & Water \\
\hline LOC & $46-43.02$ & $119-25.85$ & 210 & Locke is land \\
\hline MDW & $46-36.79$ & $119 \cdot 45.66$ & 330 & Midway, Washington \\
\hline$M+2$ & $46-33.45$ & $119-21.54$ & 146 & May Junction Two \\
\hline 013 & $46-40.14$ & $119-13.98$ & 322 & Othello Three \\
\hline PRO & $46-12.73$ & $119-41.15$ & 550 & Prosser, Washington \\
\hline \#RC1 & $46-56.71$ & $119-26.66$ & 485 & Royal City one \\
\hline RED & $46-17.92$ & $119-26.30$ & 366 & Red Mountain \\
\hline RSW & $46-23.67$ & $119 \cdot 35.48$ & 1,045 & Rattlesnake Mt. WA \\
\hline SNI & $46-27.85$ & $119-39.60$ & 312 & Snively Ranch \\
\hline WA2 & $46-45.32$ & $199-33.94$ & 244 & Wahluke slope \\
\hline WG4 & 46.01 .85 & $118-51.34$ & 511 & Wallula Gap Four \\
\hline WIS & $46-25.76$ & $119-17.26$ & 128 & Wooded I sland HA \\
\hline WRD & $46-58.20$ & $119-08.69$ & 375 & Warden, Washington \\
\hline
\end{tabular}


Figure 1. Locations of Seismograph Stations.

(See Table l for exact locations.)

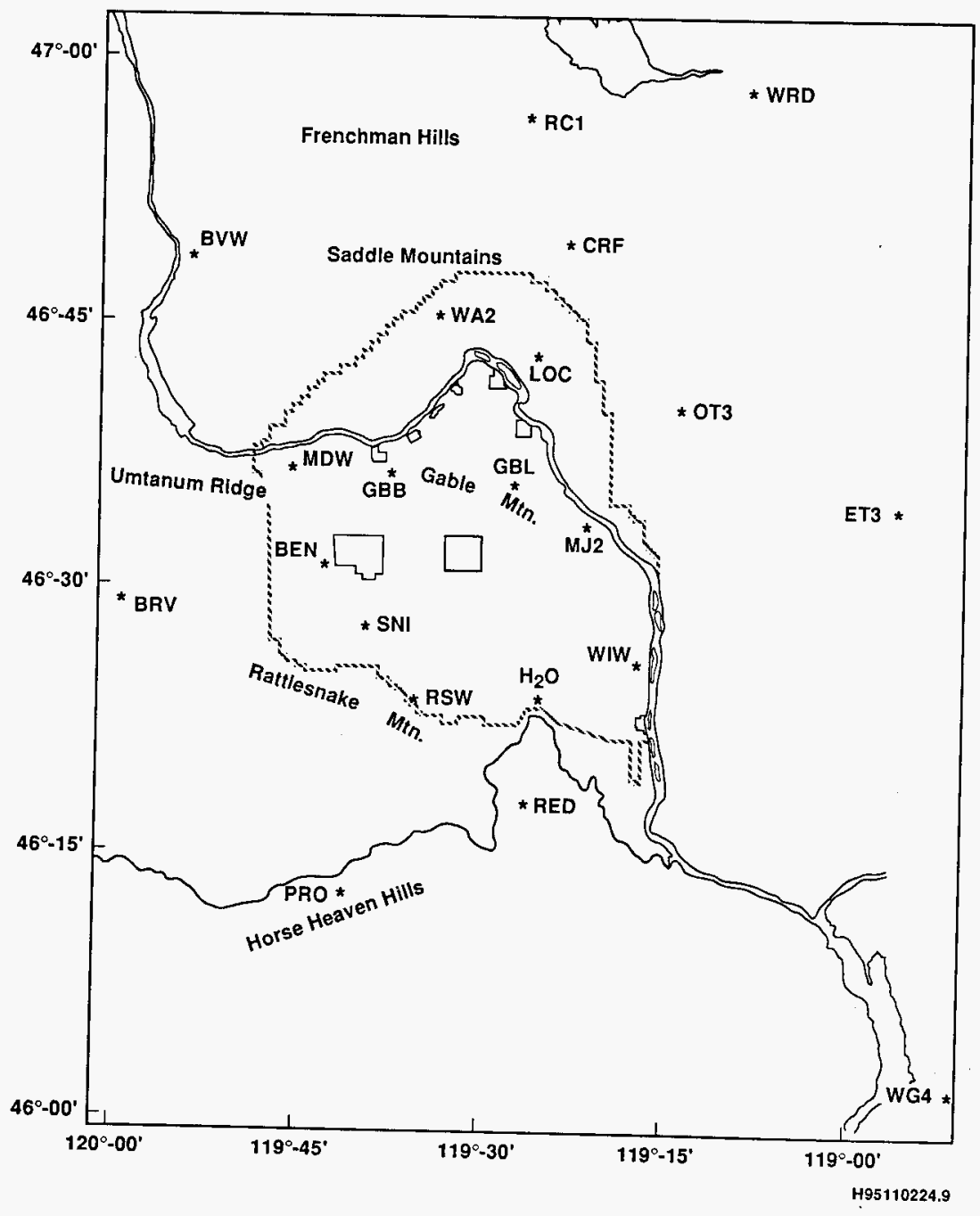


Figure 2. Locations of Seismograph Stations in the Eastern Washington Regional Network. (See Table 2 for exact locations.)

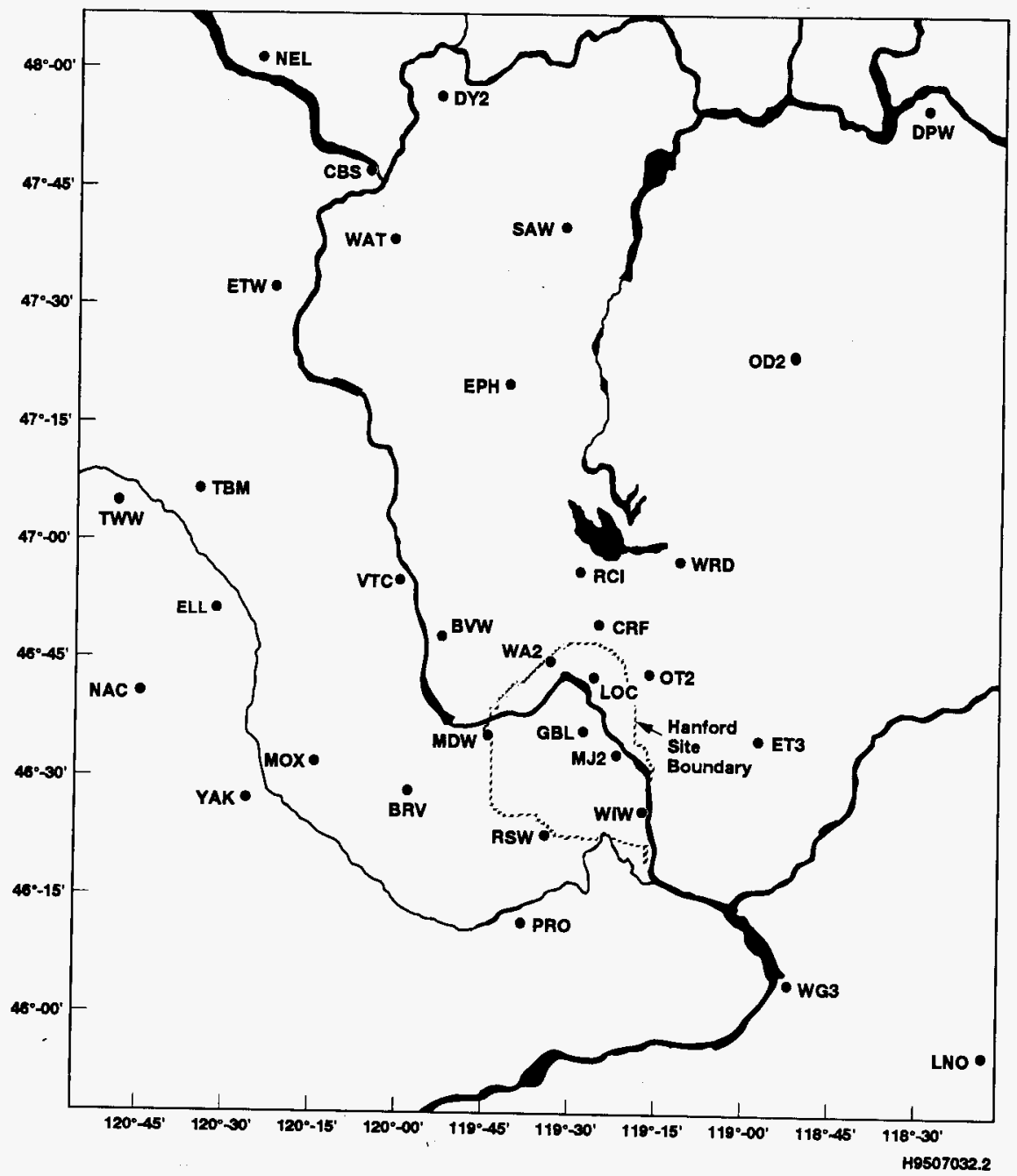


Table 2. Station Locations for the Eastern Washington Regional Network.

This table lists stations of the Eastern Washington Regional Network. The first colum is the threeletter seismic station designator. This is followed by the latitude-north in degrees, minutes, and hundredths of minutes; the longitude-west in degrees, minutes, and hundredths of minutes; elevation above sea level in meters; and the full station name. An asterisk before the three-letter designator means it is a three-component station. The locations of the stations were derived from a Global Position Satellite system (GPS).

\begin{tabular}{|c|c|c|c|c|}
\hline Stetion & $\begin{array}{l}\text { Latitude } \\
\text { Deg.Min. N. }\end{array}$ & $\begin{array}{l}\text { Longi tude } \\
\text { Deg. Min.W. }\end{array}$ & $\begin{array}{c}\text { Elevation in } \\
\text { Meters }\end{array}$ & Station Name \\
\hline BRV & $46-29.12$ & $119-59.47$ & 920 & Black Rock Valley \\
\hline BnN & $46-48.66$ & $119-52.99$ & 670 & Beverly Washington \\
\hline CBS & $47-48.26$ & $120-02.50$ & 1,067 & Chelan Butte, South \\
\hline CRF & $46-49.50$ & $119 \cdot 23.22$ & 189 & Corfu \\
\hline DPH & $47-52.25$ & $118-12.17$ & 892 & Davenport Washington \\
\hline DY2 & $47-59.11$ & $119-46.28$ & 890 & Dyer Hill Two \\
\hline Ell & $46-54.58$ & $120-33.98$ & 789 & Ellensburg \\
\hline EPH & $47-21.38$ & $119-35.76$ & 661 & Ephrata \\
\hline ET3 & $46-34.64$ & $118-56.25$ & 286 & Eltopia Three \\
\hline ETW & $47-36.26$ & $120-19.94$ & 1,477 & Entiat Washington \\
\hline $\mathrm{GBL}$ & $46-35.92$ & $119-27.58$ & 330 & Gable Mountain \\
\hline LNO & $45-52.31$ & $118-17.11$ & 771 & Lincton $\mathrm{Mt}$, Oregon \\
\hline $\mathrm{LOC}$ & $46-43.02$ & $119-25.85$ & 210 & Locke is land \\
\hline MDW & $46-36.79$ & $119-45.66$ & 330 & Midway Washington \\
\hline MJ2 & $46-33.45$ & $119-21.54$ & 146 & May Junction Two \\
\hline MOX & $46-34.64$ & $120-17.89$ & 501 & Moxee City \\
\hline NAC & $46-43.99$ & $120-49.42$ & $\cdot 728$ & Naches \\
\hline NEL & 48-04.21 & $120-20.41$ & 1,500 & Nelson Butte \\
\hline 002 & $47-23.26$ & $118-42.58$ & 553 & Odessa Two \\
\hline OT3 & $46-40.14$ & $119-13.98$ & 322 & Othello Three \\
\hline PAT & 45.52 .92 & $119-45.14$ & 262 & Paterson \\
\hline PRO & $46-12.73$ & $119-41.15$ & 550 & Prosser \\
\hline 中RC1 & $46-56.71$ & $119-26.66$ & 485 & Royal city one \\
\hline RSW & $46-23.67$ & $119-35.48$ & 1,045 & Rattlesnake Mt. WA \\
\hline SAW & $47-42.10$ & $119-24.03$ & 701 & St. Andrews \\
\hline SNI & $46-27.85$ & $119-39.60$ & 312 & Snively Ranch \\
\hline TBM & $47-10.20$ & $120-35.88$ & 1,006 & Table Mountain \\
\hline TWW & $47-08.29$ & $120-52.10$ & 1.027 & Teanaway Washingt on \\
\hline VT2 & $46-58.04$ & $119-58.95$ & 1,270 & Vantage Two \\
\hline WA2 & $46-45.32$ & $119 \cdot 33.94$ & 244 & Wahluke slope Two \\
\hline WAT & $47-41.92$ & $119-57.24$ & 821 & Waterville \\
\hline WG4 & $46 \cdot 01.85$ & $118-51.34$ & 511 & Wallula Gap Four \\
\hline WIU & $46-25.76$ & $119-17.26$ & 128 & Wooded Is land WA \\
\hline WRD & $46-58.20$ & $119-08.69$ & 375 & Warden \\
\hline YA2 & $46-31.60$ & $120-31.80$ & 652 & Yakima Two \\
\hline
\end{tabular}


WHC-SD-WM-EV-116, Rev. 0

Table 3. Seismic Channel Operational Time $(\%)$.

\begin{tabular}{|l|c|c|c|c|c|}
\hline Network & Month 1 & Month 2 & Month 3 & 2nd Quarter & FY-Year $^{\text {b }}$ \\
\hline Hanford & 99.86 & 99.82 & 99.81 & 99.81 & 99.81 \\
\hline Regional & 99.80 & 99.46 & 99.13 & 98.48 & 99.13 \\
\hline
\end{tabular}

This column is the average percentage for the second quarter.

'This column is the average percentage for fiscal year 1996.

Notes: The Hanford Seismic Network's goal is $98 \%$.

The Eastern Washington Regional Network's goal is $97 \%$.

The quarter period is January 1, 1996 through March 31, 1996. 


\subsection{EXPLANATION OF MAGNITUDE AND VELOCITY MODEL}

A11 magnitudes given in this report are Coda Amplitude Magnitudes (CAM). CAMs are the equivalent of Richter Magnitudes and apply only to Local earthquakes.

\subsection{CODA AMPLITUDE MAGNITUDE}

The AUTOSEIS program calculates the location, depth, and magnitude for earthquakes detected at the Hanford Site. This program uses the basic decay of the $S$ wave. By quantifying the expected decay of the average absolute amplitude as a function of time, any portion of the coda of an earthquake (coda segment) can be used to assign a magnitude. For the high-frequency earthquakes analyzed at the Hanford Site, the coda segment length is a 1second sample. A number of coda segments of each record can be averaged (or a median value selected) to produce a robust estimate of magnitude for each station. The average magnitude for each station is then averaged for an assigned CAM for that particular earthquake.

The Coda Amplitude Magnitude for each segment is computed from the following:

where:

$$
C A M=\log A+Q \log (t-B)
$$

$$
A=1 / 256 \sum_{i=1}^{256}\left|S_{i}\right|
$$

$S_{i}=$ signal amplitude at sample

$t=$ signal coda window in seconds $=1.0$

$Q$ describes the decay rate of the signal and $B$ describes any $D C$ bias for a particular station. Both parameters are station dependent.

\subsection{VELOCITY MODEL}

The velocities and layer depths presented in Table 4 are used by the AUTOSEIS program to locate all earthquakes on and near the Hanford Site. 
WHC-SD-WM-EV-116, Rev, 0

Table 4. Velocity Model for the Columbia Basin.

\begin{tabular}{|c|l|c|}
\hline $\begin{array}{c}\text { Depth to top of } \\
\text { velocity layer }(\mathrm{km})\end{array}$ & \multicolumn{1}{|c|}{ Stratigraphy } & $\begin{array}{c}\text { Velocity } \\
(\mathrm{km} / \mathrm{sec})\end{array}$ \\
\hline 0.0 & $\begin{array}{l}\text { Suprabasalt sediments, Saddle Mountains } \\
\text { Basalt and intercalated El lensburg Sediments }\end{array}$ & 3.7 \\
\hline 0.8 & Wanapum Basalt & 4.7 \\
\hline 1.2 & Grande Ronde Basalt & 5.2 \\
\hline 7.5 & Prebasalt Sediments & 6.1 \\
\hline 19.0 & Crystalline Basement, Layer 1 & 7.2 \\
\hline 28.0 & Crystalline Basement, Layer 2 & 8.0 \\
\hline
\end{tabular}


Table 5. Seismic Event Data. (Sheet 1 of 3 )

Event ID: The identification number assigned by the AUTOSEIS program

Date: The day of the year in Coordinated Universal Time (CUT).

Time: The origin time of the earthquake given in CUT. To convert CUT to Pacific Standard Time, subtract eight hours; to Pacific Daylight Time, subtract seven hours.

Latitude: North latitude, in degrees and minutes, of the earthquake epicenter.

Longitude: West longitude, in degrees and minutes, of the earthquake epicenter.

Depth: The depth of the earthquake in kilometers $(\mathrm{km})$.

Mag: The Coda Amplitude Magnitude (CAM). The CAM is calculated using an algorithm modified for very local earthquakes: AUTOSEIS Reference Manual, October 20, 1983, Sierra Geophysics, Inc. (SGI-M-AS-0038). See Page 5 of this report: Explanation of Magnitude and Velocity Model.

RMS: $\quad$ The root mean square residual (observed P-WAVE arrival time minus the predicted arrival time) at all stations used to locate the earthquake. It is only useful as a measure of quality of the solution when five or more well distributed stations are used in the solution. Good solutions are normally characterized by RMS values of less than about 0.3 second.

Q: $\quad$ The solution quality of the hypocenter intended to indicate the general reliability of the solution: AUTOSEIS Reference Manual, October 20, 1983, Sierra Geophysics Inc. (SGI-M-AS-0038). The quality is rated using characters $A, B, C$, and $D$.

$\begin{array}{lcll}\text { Q } & \text { Error }(\mathrm{km}) & \text { Epicenter } & \text { Focal Depth } \\ \text { A } & \leq 1.0 & \text { Excellent } & \text { Good } \\ \text { B } & \leq 2.5 & \text { Good } & \text { Fair } \\ \text { C } & \leq 5.0 & \text { Fair } & \text { Poor } \\ \text { D } & >5.0 & \text { Poor } & \text { Poor }\end{array}$

Events that occur at the edge or outside of the Hanford Seismic Network or are detected by fewer than five stations very often have a $Q$ of $C$ or $D$.

*Denotes events that occurred during this quarter. 
Table 5. Seismic Event Data. (Sheet 2 of 3)

\begin{tabular}{|c|c|c|c|c|c|c|c|c|c|}
\hline EVENT ID & DATE & TIME & LATITUDE & LONGI TUDE & $\begin{array}{l}\text { DEPTH } \\
\text { (KM) }\end{array}$ & MAG & RMS & a & LOCATION \\
\hline $96590046^{*}$ & $3 / 30$ & $01: 06: 01.34$ & $46-27.57$ & $119-34.75$ & 16.88 & 0.29 & 0.05 & $A$ & $\begin{array}{l}3 \mathrm{~km} \text { south of Goose } \\
\text { Egg Hill or } 9 \mathrm{~km} \text { south of } 200 \mathrm{E} \text { on } \\
\text { Hanford }\end{array}$ \\
\hline $96586130 *$ & $3 / 26$ & $03: 08: 21.58$ & $46-44.89$ & $119-39.11$ & 1.62 & 1.17 & 0.04 & B & $\begin{array}{l}-7 \mathrm{~km} \text { north of "K" Basins on } \\
\text { Hanford }\end{array}$ \\
\hline $96583601 *$ & $3 / 23$ & $14: 30: 43.04$ & $46-24.32$ & $119-16.33$ & 0.68 & 0.70 & 0.06 & B & $\begin{array}{l}\text { North end of Johnson Island on } \\
\text { Hanford }\end{array}$ \\
\hline $96581389 *$ & $3 / 21$ & $09: 23: 15.58$ & $46-30.90$ & $119-30.57$ & 22.42 & 0.93 & 0.05 & $A$ & $\begin{array}{l}3 \mathrm{~km} \text { SSE of } 200 E \mathrm{\&}-10 \mathrm{~km} \text { NW } \\
\text { of the LIGO vertex on Hanford }\end{array}$ \\
\hline $96567505^{*}$ & $3 / 07$ & $12: 11: 26.76$ & $46-40.33$ & $119-08.39$ & 3.39 & 0.34 & 0.04 & B & $\begin{array}{l}\text { South end of Eagle Lakes, - } 15 \mathrm{~km} \\
\text { east of the eastern Hanford } \\
\text { boundary }\end{array}$ \\
\hline $96564061 *$ & $3 / 04$ & $01: 28: 56.80$ & $46-24.11$ & $119-16.11$ & 1.09 & 0.48 & 0.40 & B & $\begin{array}{l}\text { North end of Johnson Is land on } \\
\text { Hanford }\end{array}$ \\
\hline $96555502^{*}$ & $2 / 24$ & $12: 07: 14.38$ & $46-54.19$ & $119-34.38$ & 0.39 & 1.48 & 0.04 & B & $\begin{array}{l}-4 \mathrm{~km} \text { east of Royal City, WA \& - } \\
23 \mathrm{~km} \text { north of " } \mathrm{N} \text { " Reactor }\end{array}$ \\
\hline $96530902^{\star}$ & $1 / 30$ & $21: 46: 53.28$ & $46-24.01$ & $119-13.13$ & 0.95 & 0.72 & 0.03 & C & $\begin{array}{l}5 \mathrm{~km} \text { east of the north end of } \\
\text { Johnson Is. and } 7 \mathrm{~km} \text { east of the } \\
300 \text { Area on Hanford }\end{array}$ \\
\hline $96525666^{*}$ & $1 / 25$ & $16: 04: 45.77$ & $46-49.01$ & $119-22.83$ & 1.11 & 1.14 & 0.03 & A & - $5 \mathrm{~km}$ east of Corfu, UA \\
\hline $96525032^{*}$ & $1 / 25$ & $00: 47: 01.15$ & $46-35.24$ & $119-40.40$ & 9.57 & 0.68 & 0.04 & A & $\begin{array}{l}1 \mathrm{~km} \text { NW of } 200 \mathrm{~W} \text { on Army Loop } \\
\text { road on Hanford }\end{array}$ \\
\hline 95851288 & $12 / 17$ & $06: 58: 05.49$ & $46-43.40$ & $919-33.47$ & 1.95 & 0.41 & 0.03 & A & $\begin{array}{l}\text { - } 5 \text { km north of "W" reactor on } \\
\text { Hanford }\end{array}$ \\
\hline 96844874 & $12 / 10$ & $21: 07: 05.81$ & $46-39.31$ & $119-41.49$ & 12.84 & 0.31 & 0.05 & B & $\begin{array}{l}\text { - } 13 \mathrm{~km} \text { east of Priest Rapids Dam } \\
\text { on Hanford }\end{array}$ \\
\hline 95822745 & $11 / 18$ & $18: 00: 24.89$ & $46-27.63$ & $119-45.00$ & 18.66 & 1.43 & 0.07 & $B$ & - $2 \mathrm{~km}$ su of Lower Snively Spring \\
\hline 95820872 & $11 / 16$ & $21: 04: 06.58$ & $46-38.92$ & $119-46.39$ & 1.02 & 1.28 & 0.05 & c & $\begin{array}{l}7.5 \mathrm{~km} \text { east of Priest Repids } \\
\text { Dam ot the Hanford boundary }\end{array}$ \\
\hline 95806888 & $11 / 02$ & $21: 26: 28.86$ & $46-30.37$ & $119-37.37$ & 8.71 & 0.28 & 0.02 & $A$ & $\begin{array}{l}\text { a SE corner of } 200 \mathrm{w} \text {, near Hanford } \\
\text { Hell } 699-29-70 \text { on Hanford }\end{array}$ \\
\hline
\end{tabular}


Table 5. Seismic Event Data. (Sheet 2 of 3 )

\begin{tabular}{|c|c|c|c|c|c|c|c|c|c|}
\hline 95806600 & $11 / 02$ & $14: 30: 14.44$ & $46-09.00$ & $119-34.55$ & 18.17 & 3.25 & 0.08 & c & $-15 \mathrm{~km}$ ESE of Prosser WA \\
\hline 95806425 & $11 / 02$ & $10: 15: 17.87$ & $46-30.21$ & $118-37.52$ & 8.64 & -0.29 & 0.01 & B & $\begin{array}{l}\text { a SE corner of 200w, near Hanford } \\
\text { Hell \#699-29-70 }\end{array}$ \\
\hline 95806068 & $11 / 02$ & $04: 39: 10.02$ & $46-30.29$ & $119-37.40$ & 8.45 & 0.00 & 0.01 & B & $\begin{array}{l}\text { a SE corner of } 200 w \text {, near Hanford } \\
\text { Hell \# } 899-29-70 \text { on Hanford }\end{array}$ \\
\hline 95797647 & $10 / 24$ & $15: 37: 10.55$ & $46-47.52$ & $119-37.84$ & 13.52 & 0.75 & 0.02 & $B$ & - $5 \mathrm{~km}$ SE of SMmyrna $\mathrm{HA}$ \\
\hline 95793510 & $10 / 20$ & $12: 19: 53.79$ & $46 \cdot 38.84$ & $119-46.70$ & 0.15 & 0.94 & 0.06 & B & $\begin{array}{l}-7 \mathrm{~km} \mathrm{NW} \text { of } 200 \mathrm{w} \text {, near Juniper } \\
\text { Springs on Hanford }\end{array}$ \\
\hline 95793000 & $10 / 20$ & $00: 00: 35.16$ & $46-31.04$ & $119 \cdot 35.37$ & 8.07 & .0 .56 & 0.01 & B & $\begin{array}{l}\text { a SE corner of } 200 \text {, near Hanford } \\
\text { Nell \# } 699-29-70 \text { on Hanford. }\end{array}$ \\
\hline 95776509 & $10 / 03$ & $12: 17: 49.16$ & $46-20.91$ & $119-38.96$ & 21.52 & 2.37 & 0.06 & B & - $4 \mathrm{~km}$ WSW of Mcthorter Springs \\
\hline
\end{tabular}


WHC-SD-WM-EV-116, Rev. 0

\subsection{GEOLOGY AND TECTONIC ANALYSIS}

\subsection{DEPTH OF EARTHQUAKES}

Studies of seismicity at the Hanford Site have shown that the seismicity is related to the following crustal stratigraphy (layers of rock types) (DOE 1988).

- The Columbia River Basalt Group (CRBG) (approximately 0-5 km deep)

- The prebasalt sediments (approximately $5-10 \mathrm{~km}$ deep)

- The crystalline basement (greater than approximately $10 \mathrm{~km}$ ).

Since the early 1980 s deep boreholes have been drilled for hydrocarbon exploration. These boreholes have made accurate measurements and compositional analysis of the CRBG and the prebasalt sediments possible (Reidel and others, 1987, 1994). The thickness of the prebasalt sediments and nature of the crystalline basement, however, are still poorly understood. The difference between the thickness 7 isted here and the thickness of the crustal layers in the velocity model in Table 4 reflect data specific for the Hanford Site rather than the University of Washington's crustal model for eastern Washington.

Since records have been kept, about 75 percent of the earthquakes at the Hanford site have originated in the CRBG layer. The prebasalt sediments have had about 7 percent of the events and the crystalline basement has had 18 percent.

For fiscal year (FY) 1996, 23 events were located (Table 2); 11 events ( 48 percent) occurred in the basalt, 5 events (22 percent) in the prebasalt sediments, and 7 events ( 30 percent) in the crystalline basement.

\subsection{TECTONIC PATTERN}

Studies at Hanford have concluded that earthquakes can occur in the following six different tectonic environments (earthquake sources) at the Hanford Site and in the Columbia Basin of eastern Washington (Geomatrix 1996).

- Reverse thrust faults. Reverse/thrust faults in the CRBG associated with major anticlinal ridges such as Rattlesnake Mountain, Yakima Ridge and Umtanum Ridge could produce the largest earthquakes.

- Secondary faults. These are associated with the major anticlinal ridges.

- Swarm areas. Small geographic areas of unknown geologic structure produce clusters of events (swarms), usually in the CRBG in synclinal valleys. These clusters consist of a series of small shocks with no one outstanding principle event. Swarms occur over 
a period of days or months and the events may number into the hundreds and then quit only to start again at a later date. This differs from the sequence of foreshocks, mainshock, and trailing off aftershocks that have the same epicenter or are associated with the same fault system. Three principal swarm areas are known at the Hanford Site. One is the Wooded Island Swarm Area along the Columbia River near the 300 Area. The second area, the Coyote Rapids Swarm Area, extends from the vicinity of the $100 \mathrm{~K}$ Area north-northeast along the Columbia River Horn to the vicinity of $100 \mathrm{~N}$ Area. The third major swarm area is along the Saddle Mountains on the northern boundary of the Hanford Site. Other earthquake swarm areas are present, but activity is less frequent.

- The entire Columbia Basin. The entire basin, including the Hanford Site, could produce a "floating" earthquake. A floating earthquake is one that, for seismic design purposes, can happen anywhere in a tectonic province and is not associated with any known geologic structure. It is classified as a random event by Seismic Monitoring for purposes of seismic design and vibratory ground motion studies.

- Basement source structures. Studies suggest that major earthquakes can originate in tectonic structures in the crystalline basement. Because very little is known about geologic structures in the crystalline basement beneath the Hanford Site, earthquakes cannot be directly tied to a mapped fault.

Earthquakes occurring in the crystalline basement without known sources are treated as random events for seismic hazards analysis and seismic design development.

- The Cascadia Subduction Zone. This source recently has been postulated to be capable of producing a 9-CAM earthquake. Because this source is along the western boundary of Washington State and outside the Hanford Array, the Cascadia Subduction Zone is not an earthquake source that is monitored at the Hanford Site, so subduction zone earthquakes are not reported here. Because any earthquake along the Cascadia Subduction zone can have a significant impact on the Hanford Site (Geomatrix, 1996), the University of Washington monitors and reports on this earthquake source for the U.S. Department of Energy (DOE). Ground motion from any moderate or larger Cascadia Subduction Zone earthquake is detected by seismometers in the HSN.

\subsection{CURRENT TECTONIC ACTIVITY}

The locations of all events with CAMs greater than 1.0 for FY 1996 are shown on Figure 3. The locations of all seismic events for FY 1996 are shown in Figure 4. Figure 5 is a tectonic map of the Yakima Fold Belt and Hanford 
Figure 3. Located Earthquakes Magnitude 1.0 and Greater: January 1, 1996, and March 31, 1996. (Coda Amplitude Scale

is shown at the top of the Map.)

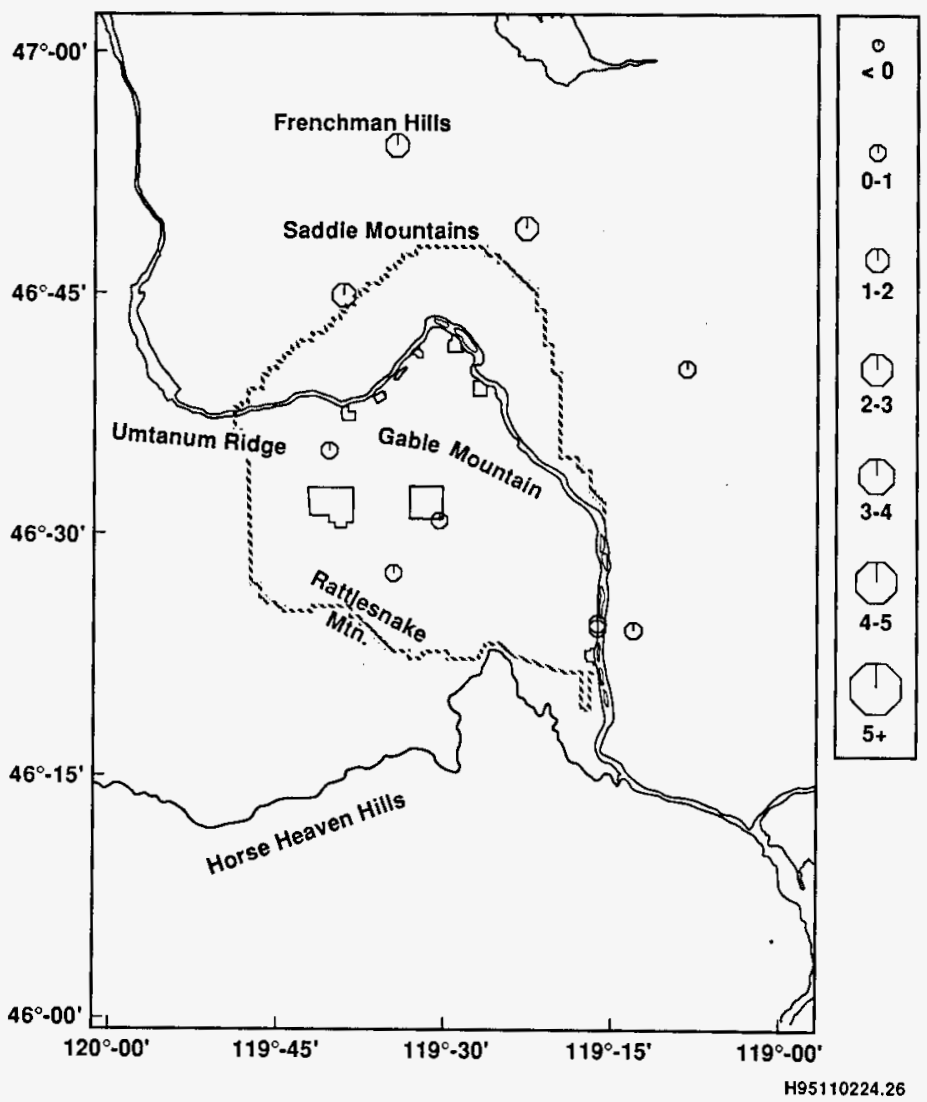


Figure 4. Locations of A11 FY 1996 Events: October 1, 1995, and March 31, 1996. (Coda Amplitude Magnitude

Scale is shown at the top of the map.)

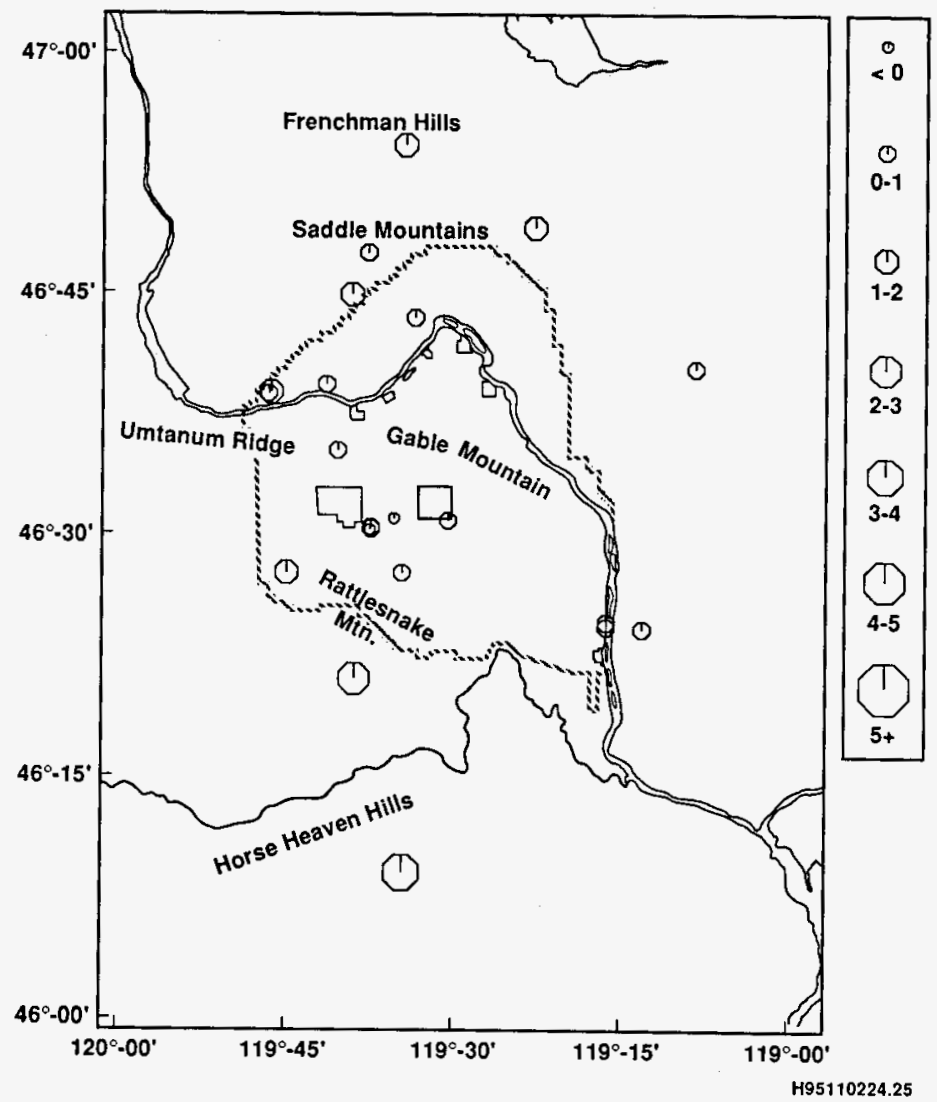


Figure 5. Structural and Tectonic Map of Columbia Basin Showing Major Seismic Source Structures.

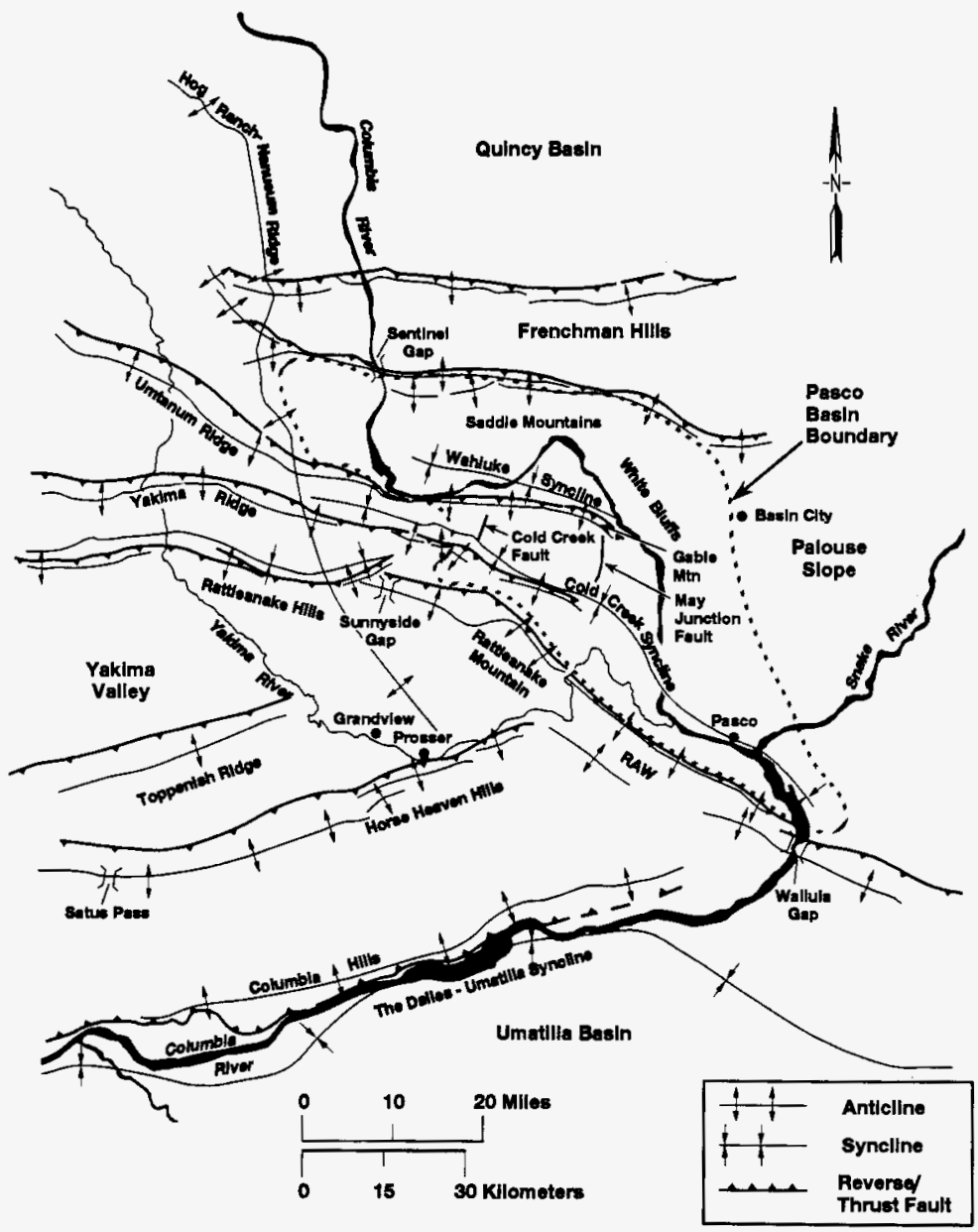

Mst10024.10 
Site. The Yakima Fold Belt is the main tectonic province of concern for the Hanford Site. The figure shows all the major mapped ridges and faults that are potential seismic sources. These figures should be referred to for the following discussions.

\subsubsection{Reverse/Thrust Faults on Major Anticlinal Ridges}

During this reporting period, no earthquakes appear to be associated with any of the major anticlinal ridges.

\subsubsection{Secondary Structures on Main Anticlinal Ridges}

During this reporting period, no events were located on mapped secondary geologic structures on major anticlinal ridges.

\subsubsection{Swarm Area Activity}

During this reporting period, 7 events ( 30 percent of a 11 events located) were located in earthquake swarm areas. The swarm areas are discussed in Sections 4.3.3.1 through 4.3.3.4.

4.3.3.1 Saddle Mountains Swarm Area. The Saddle Mountains swarm area experienced three small (<2 CAM) events during FY 1996. Two events occurred near Corfu (January 25, 1996, and April 2, 1996) and one event, February 24, 1996, occurred near Royal City. The April 2, 1996, event occurred in the Saddle Mountains at a shallow depth near a known fault that separates two segments of the Saddle Mountains structure. This earthquake might be fault controlled.

4.3.3.2 Coyote Rapids Swarm Area. One earthquake occurred in the Coyote Rapids swarm on December 17, 1995. This was a small-magnitude earthquake ( 1.95 CAM) at the north end of the swarm area near the $100 \mathrm{~N}$ Area.

4.3.3.3 Wooded Island Swarm Area. Three events occurred here during FY 1996: January 30, 1996, March 4, 1996, and March 23, 1996. Al1 three events occurred near Johnson Island at the north end of the swarm and were less than 1 CAM. 
WHC-SD-WM-EV-116, Rev. 0

\subsubsection{0ther Swarm Areas.}

Eagle Lakes Swarm Area. One event occurred on the south flank of the eastern portion of the Saddle Mountains near the Eagle Lakes area. This has been a swarm area in the past. The event occurred on March 7, 1996, and had a CAM of 1.62 at a depth of $3.4 \mathrm{~km}$ in the CRBG. Because of its location and depth, this earthquake could have occurred along the Saddle Mountains fault.

Wahluke Syncline Swarm Area. Three small (<2 CAM) events occurred in the CRBG in the Wahluke syncline between the Priest Rapids Dam area and $100 \mathrm{~K}$ Area. The events of October 20, 1995, and November 16, 1995, occurred near the axis of the syncline. The event of March 26, 1996, occurred farther north.

Cold Creek Syncline-Goose Egg Hill Swarm Area. Three small (<l CAM) events occurred along the axis of the Cold Creek syncline, north of the Yakima Ridge fault zone and southeast of the 200 West Area. These earthquakes occurred between 8 and $9 \mathrm{~km}$ deep in the prebasalt sediments. Three events occurred on November 2, 1995; the fourth event occurred on October 20, 1995. Because of the close proximity and short time between them, these events are interpreted to have occurred in a swarm. Four events occurred in this area during FY 1995.

These earthquakes might be associated with the Umtanum-Gable Mountain fault zone, but because they occurred in the prebasalt sediments and because studies of the Umtanum-Gable Mountain fault suggested that the fault does not extend below the basalt, these events presently are not considered to be associated with that fault.

\subsubsection{Random or Floating Event Areas}

Eight events that occurred during the reporting period ( 30 percent of all events located) are classified as random events. The areas are discussed in Sections 4.3.4.1 through 4.3.4.6.

4.3.4.1 Saddle Mountains Area. On October 24, 1995, a smal1 (<1 CAM) event occurred at a depth of $13.5 \mathrm{~km}$ in the crystalline basement on the south flank of the Saddle Mountains. This is classified as a random event because no known fault occurs at this depth. This earthquake could have been along the Saddle Mountains fault zone, but because the earthquake occurred below the basalt in the crystalline basement, and because studies of the Saddle Mountains fault suggest that this fault does not extend below the basalt, this event is presently not considered to be associated with that fault.

4.3.4.2 Wahluke Syncline Area. A small (<1 CAM) event occurred in the Wahluke syncline at a depth of nearly $13 \mathrm{~km}$ on December 10, 1995. This event occurred in the crystalline basement near the $100 \mathrm{~K}$ Area, which is the same general area as the Wahluke swarm area described in Section 4.3.3.4. This location contains no known structure, but the area was active during $F Y 1995$.

4.3.4.3 200 West Area. One event occurred on January 25, 1996, north of 200 West Area at a depth of $9.6 \mathrm{~km}$. This depth places the event near the crystalline basement-prebasalt sediment contact. This event is classified as a random event because no known fault occurs at that location. This 
WHC-SD-WM-EV-116, Rev. 0

earthquake might have occurred along the Umtanum-Gable Mountain fault zone, but because the earthquake occurred below the basalt and because studies of the Umtanum-Gable Mountain fault suggest that this fault does not extend below the basalt, this event is presently not considered to have occurred along that fault.

4.3.4.4 Cold Creek Syncline Area-Goose Egg Hill Swarm Area. Two small (<1 CAM) earthquakes occurred on March 21, and March 30, 1996, in the crystalline basement 16-23 km deep along the axis of the Cold Creek syncline southeast of the 200 West Area. Earthquakes also occurred there in FY 1995. Both events occurred near earthquakes that had occurred at a shallower depths (6.5-8.5 km deep) in the prebasalt sediments (see Section 4.3.3.4).

4.3.4.5 Rattlesnake Mountain Area. Two sma11 (<2.4 CAM) earthquakes occurred in the Rattlesnake Mountain area in the crystalline basement at depths of between 18 and $22 \mathrm{~km}$. The November 18, 1995, event, which had a CAM of 1.43, occurred in the Snively Basin area at a depth of $18.7 \mathrm{~km}$. Because of its great depth, this earthquake cannot be related to any known geologic structure.

A 2.37-CAM earthquake occurred on October 3, 1995, on the south flank of Rattlesnake Mountain. The event occurred in the crystalline basement at a depth of about $21 \mathrm{~km}$. This earthquake might have occurred along the subsurface extension of the Rattlesnake Mountain fault zone, but because the earthquake occurred in the crystalline basement and because studies of the Rattlesnake Mountain fault suggested that the fault does not extend below the basalt, this event presently is not considered to be caused by that fault.

4.3.4.6 Horse Heaven Hills Area. A 3.25-CAM earthquake occurred in the Horse Heaven $\mathrm{Hill}$ s on November 2, 1995, at a depth of about $18.2 \mathrm{~km}$ in the crystalline basement. Because of its great depth, this earthquake cannot be correlated to any known structure. This earthquake might have occurred along the subsurface extension of the Horse Heaven Hills fault zone, but because the earthquake occurred in the crystalline basement and because studies of the Horse Heaven Hills fault suggested that the fault does not extend below the basalt, this event presently is not considered to be caused by that fault. 


\subsection{REFERENCES}

Geomatrix, 1996, Probabilistic Seismic Hazard Analysis, DOE Hanford Site, Washington, WHC-SD-W236A-TI-002, Rev. 1, Westinghouse Hanford Company, Richland, Washington.

Reidel, S. P., N. P. Campbe11, K. R. Fecht, and K. A. Lindsey, 1994, "Late Cenozoic Structure and Stratigraphy of South-Central Washington," in Cheney, E. and R. Lasmanis, Eds, Regional Geology of Washington State, , Washington Division of Geology and Earth Resources Bulletin 80 p. 159-180, Olympia, Washington.

Reide1, S.P., K. R. Fecht, M. C. Hagood, and T. L. Tolan, 1989, "Geologic Development of the Central Columbia Plateau," in Reidel, S.P. and P. R. Hooper, Eds., Volcanism and Tectonism in the Columbia River Flood-Basalt Province Geological Society of America Special Paper 239, p. 247-264.

DOE, 1988, Site Characterization Plan for the Reference Location, Hanford, Washington-Consultation Draft, Report DOE/RW-0164, Vol. 1, U.S. Department of Energy, Washington, D.C. 
WHC-SD-WM-EV-116, Rev. 0

This page intentionally left blank. 
WHC-SD-WM-EV-116, Rev. 0

\section{DISTRIBUTION}

Number of Copies

Onsite

$2 \quad U . S$. Department of Eneray,

Richland Operations office

M. J. Furman

H4-85

K. M. Thompson

$\mathrm{H} 4-83$

1 Bechtel Hanford, Inc.

P. J. Mackey B3-15

35

Westinghouse Hanford Company

M. V. Berriochoa

J. A. Caggiano

A3-01

D. A. Conners

A. J. Diliberto (2)

H6-06

J. W. Fassett

T5-11

J. C. Fulton

H6-10

F. T. Green

D. C. Hartshorn

H6-06

R3-11

R. A. Meznarich

H6-29

D. L. Mitchell

(15) $\begin{array}{r}\mathrm{H} 6-06 \\ \mathrm{H} 6-30\end{array}$

S. R. Moreno

H6-29

S. P. Reide?

B3-06

E. R. Siciliano

H6-06

A. M. Tallman

$\mathrm{HO}-31$

R. R. Thompson

H6-30

R2-12

J. D. Williams

H6- 30

B. D. Williamson

B3-15

M. I. Wood

T3-0I

M. T. York

H6-29

Central Files

A3-88 
WHC-SD-WM-EV-116, Rev. 0

This page intentionally left blank.

Distr-2 


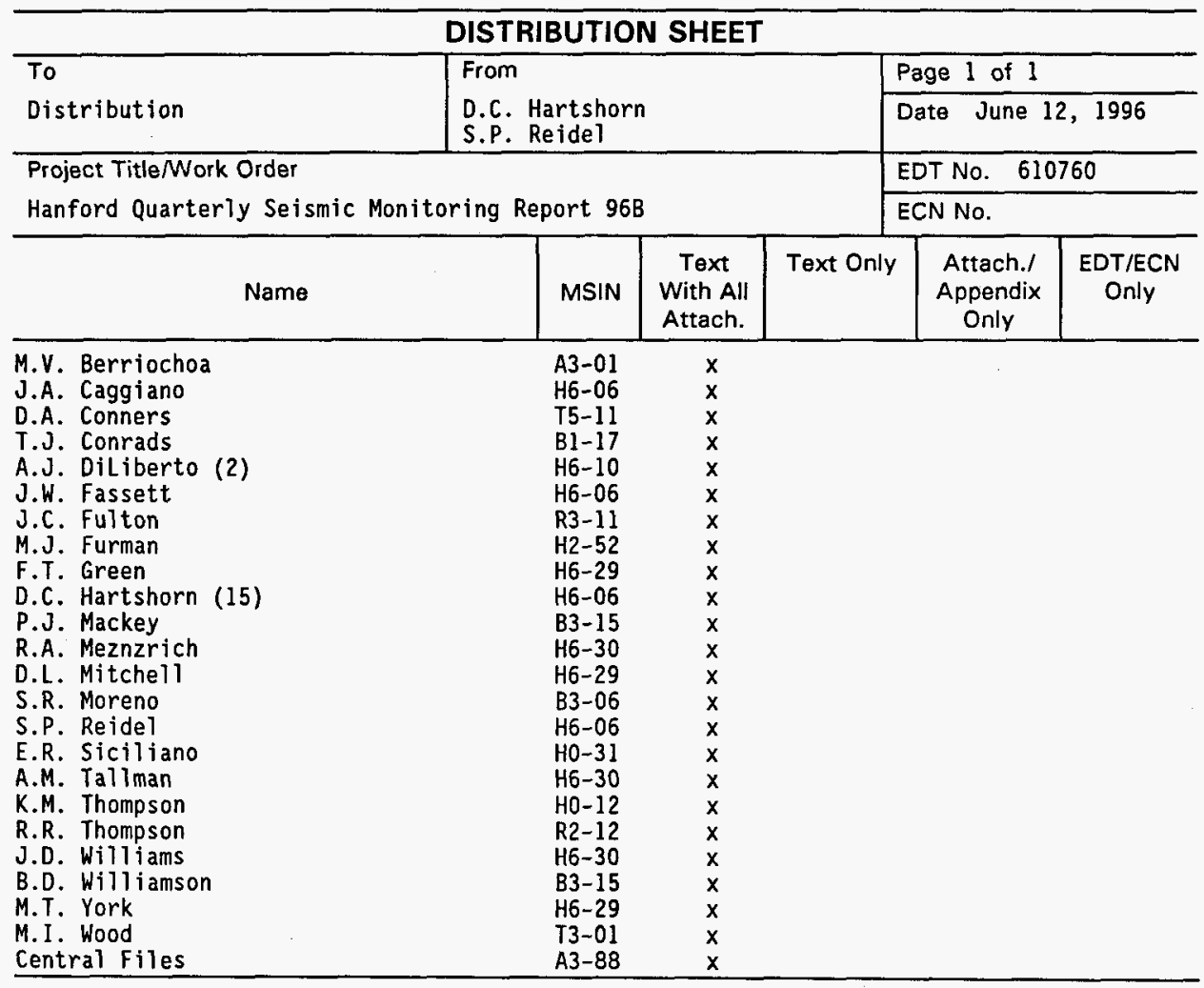

